\title{
Cation distribution of pseudobrookite-type titanates and their phase stability
}

\author{
Yutaka OHYA ${ }^{\dagger}$, Yukihiro KAWAUCHI and Takayuki BAN \\ Gifu University, Department of Chemistry and Biomolecular Science, 1-1 Yanagido, Gifu 501-1193, Japan
}

Pseudobrookite-type titanate has two types of oxide octahedra for different cation types. The cation distributions in the octahedra of three pseudobrookite type oxides, $\mathrm{Al}_{2} \mathrm{TiO}_{5}, \mathrm{MgTi}_{2} \mathrm{O}_{5}$ and $\mathrm{Fe}_{2} \mathrm{TiO}_{5}$, and in a solid solution of $0.5 \mathrm{Al}_{2} \mathrm{TiO}_{5}-0.5 \mathrm{MgTi}_{2} \mathrm{O}_{5}$ were studied by the Rietveld method. The analysis revealed that the cation distributions of $\mathrm{Al}_{2} \mathrm{TiO}_{5}$ and $\mathrm{Fe}_{2} \mathrm{TiO}_{5}$ did not depend on the annealing temperature, whereas that of $\mathrm{MgTi}_{2} \mathrm{O}_{5}$ depended on the annealing temperature. The estimated cation distributions determined by the Rietveld method agreed with those determined by bond valence sum estimation. The configuration entropies of $\mathrm{Al}_{2} \mathrm{TiO}_{5}$ and $\mathrm{Fe}_{2} \mathrm{TiO}_{5}$ were almost the same as that of the maximum value of the random distribution of cations. Although the configuration entropy stabilized $\mathrm{Al}_{2} \mathrm{TiO}_{5}$ thermodynamically, the decomposition of $\mathrm{Al}_{2} \mathrm{TiO}_{5}$ should be attributed to the stable nature of corundum, and the rather "stretched" structure of $\mathrm{Al}_{2} \mathrm{TiO}_{5}$ would also cause its instability at low temperature.

(C2017 The Ceramic Society of Japan. All rights reserved.

Key-words : Pseudobrookite-type titanate, Cation distribution, Rietveld method, Configuration entropy

[Received April 17, 2017; Accepted June 22, 2017]

\section{Introduction}

Pseudobrookite-type titanates, such as $\mathrm{Al}_{2} \mathrm{TiO}_{5}, \mathrm{MgTi}_{2} \mathrm{O}_{5}$ and $\mathrm{Fe}_{2} \mathrm{TiO}_{5}$, show large thermal expansion anisotropy, ${ }^{1)}$ and their sintering specimens contain grain boundary cracks. ${ }^{2)}$ The grain boundary cracks are due to thermal stresses on grain boundaries caused by anisotropic contraction during cooling. ${ }^{3), 4)}$ These grain boundary cracks cause low mechanical strength and low thermal expansion in ceramics. The latter property is attributed to the fact that thermal expansion in the direction of a large thermal expansion coefficient only fills the gap of a grain boundary crack. Among the three titanates above, $\mathrm{Al}_{2} \mathrm{TiO}_{5}$ exhibits the largest thermal expansion anisotropy and a negative expansion coefficient along one crystallographic direction; therefore, the ceramics of $\mathrm{Al}_{2} \mathrm{TiO}_{5}$ have a lower thermal expansion than those of $\mathrm{MgTi}_{2} \mathrm{O}_{5}$ and $\mathrm{Fe}_{2} \mathrm{TiO}_{5} . \mathrm{Al}_{2} \mathrm{TiO}_{5}$ ceramics are applied to the materials of a diesel particulate filter because of their high thermal shock resistance. 5),6) The mechanical strength can be improved by reducing the amount of grain boundary cracks by suppressing grain growth ${ }^{7)}$ because a sample with a large grain size tends to have a large amount of grain boundary cracks and low mechanical strength. However, this also brings about an increasing thermal expansion coefficient. We recently proposed the microstructure of $\mathrm{Al}_{2} \mathrm{TiO}_{5}$ ceramics with a small amount of rectangular large crystals distributed in the small-grained matrix. ${ }^{8)}$ The resultant ceramics have low thermal expansion and rather good mechanical properties.

Pseudobrookite-type oxides have interesting crystal chemistry. ${ }^{1)}$ This structure has two types of cation octahedral sites, namely, $4 \mathrm{c}$ and $8 \mathrm{f}$. In pseudobrookite-type titanates, two types of cations and three cations of nominal formula distribute into the two types of octahedral sites in the crystal. This distribution increases the configuration entropy, and the structure becomes stable at higher temperature. This stabilization is pronounced in the case of $\mathrm{Al}_{2} \mathrm{TiO}_{5} .{ }^{1)}$ This titanate is stable above $1280^{\circ} \mathrm{C}$, ${ }^{\text {) }}$

\footnotetext{
Corresponding author: Y. Ohya; E-mail: ohya@gifu-u.ac.jp
}

and the formation reaction of $\mathrm{Al}_{2} \mathrm{TiO}_{5}$ from the mixture of rutile and corundum is endothermic, i.e., $\mathrm{Al}_{2} \mathrm{TiO}_{5}$ is stabilized by the configuration entropy. This also means that $\mathrm{Al}_{2} \mathrm{TiO}_{5}$ decomposes at lower temperature, which is a problem for practical applications of $\mathrm{Al}_{2} \mathrm{TiO}_{5}$ ceramics.

The change in the distribution of the two types of cations in the two octahedral sites is very interesting. Wechsler and Navrotsky studied the dependence of the cation distribution in $\mathrm{MgTi}_{2} \mathrm{O}_{5}$ on temperature according to the change in the dimension of the $c$-axis ${ }^{10)}$ and found that occupancy by $\mathrm{Ti}^{4+}$ in the $4 \mathrm{c}$ site decreased with decreasing temperature. Brown and Navrotsky ${ }^{11)}$ and Yang and Hazen ${ }^{12)}$ also studied the cation distribution in $\mathrm{MgTi}_{2} \mathrm{O}_{5}$ and obtained the same results. Norberg et al. ${ }^{13)}$ reported the cation distribution in $\mathrm{Al}_{2} \mathrm{TiO}_{5}$, which was fabricated by the rapid cooling of a melt, as ${ }^{[4 \mathrm{c}]}\left[\mathrm{Al}_{0.626} \mathrm{Ti}_{0.374}\right]^{[8 \mathrm{ff}]}\left[\mathrm{Al}_{0.687} \mathrm{Ti}_{0.313}\right] \mathrm{O}_{5}$. The cation was distributed almost randomly, and the $\mathrm{Ti}^{4+}$ ion slightly favored the $4 \mathrm{c}$ site. Skala et al. ${ }^{14)}$ studied the cation distribution of $\mathrm{Al}_{2} \mathrm{TiO}_{5}$ by high temperature neutron and X-ray diffractometry and reported an almost random distribution and little preference of $\mathrm{Ti}^{4+}$ ion for the $4 \mathrm{c}$ site below $800^{\circ} \mathrm{C}$, which was the same tendency found by Norberg. Their measurement at $1200^{\circ} \mathrm{C}$ is interesting, but the analyzed stoichiometry became an aluminum rich composition from the nominal formula of $\mathrm{Al}_{2} \mathrm{TiO}_{5}$.

Here, we report the results of our investigation on the cation distribution by the Rietveld method and bond valence sum. We also evaluated the change in the configuration entropy of the pseudobrookite type oxides, $\mathrm{Al}_{2} \mathrm{TiO}_{5}, \mathrm{MgTi}_{2} \mathrm{O}_{5}$, and $\mathrm{Fe}_{2} \mathrm{TiO}_{5}$ as well as a $0.5 \mathrm{Al}_{2} \mathrm{TiO}_{5}-0.5 \mathrm{MgTi}_{2} \mathrm{O}_{5}$ solid solution.

The pseudobrookite-type titanate belongs to a orthorhombic crystal system, and there is some confusion about its space group. Here, we adopt $B b m m$ as the space group after Pauling, ${ }^{15)}$ in which the length of the $b$-axis is longest and the $c$-axis is shortest.

\section{Experimental procedure}

The starting powders used in the experiments were corundum (99.99\% pure, AKP-20, Sumitomo Chemical, Japan), rutile (99.98\% pure, TP-3, Fuji Titanium Industry, Japan), $\mathrm{Mg}(\mathrm{OH})_{2}$ 
(99.9\% pure, MH-30, Iwatani Chemical Industry, Japan), and hematile (99.99\% pure, Kojundo Chemical Lab., Japan). These powders were weighed at appropriate ratios and mixed in an alumina mill and nylon coated metal balls. The weighted molar ratios of $\mathrm{Al}_{2} \mathrm{TiO}_{5}$ were shifted from the equimolar ratio to $\mathrm{Al}_{2} \mathrm{O}_{3}: \mathrm{TiO}_{2}=1: 1.02$ and $1.02: 1$ to verify the solid solution range. As a result, there were only slight differences between the two ratios and no detectable range of solid solution, so the results with lower $R_{\mathrm{wp}}$ are described hereafter as the data of $\mathrm{Al}_{2} \mathrm{TiO}_{5}$. After mixing, the samples were molded and CIPed into discs of $10 \mathrm{~mm} \phi \times 5 \mathrm{~mm}$ under $100 \mathrm{MPa}$. The discs of $\mathrm{Al}_{2} \mathrm{TiO}_{5}$ and $\mathrm{MgTi}_{2} \mathrm{O}_{5}$ were sintered at $1500^{\circ} \mathrm{C}$ for $2 \mathrm{~h}$ in an electric furnace and subsequently soaked at various lower temperatures for a long time and then water quenched. After sintering at $1500^{\circ} \mathrm{C}$, $\mathrm{Al}_{2} \mathrm{TiO}_{5}$ samples were annealed at $1300,1200,1100$ and $600^{\circ} \mathrm{C}$ for 1,10 and $100 \mathrm{~h} . \mathrm{MgTi}_{2} \mathrm{O}_{5}$ samples were annealed at 1400 to $400^{\circ} \mathrm{C}$ for 100 and $200 \mathrm{~h}$ after sintering at $1500^{\circ} \mathrm{C}$. Additionally we investigated the cation distribution of the $0.5 \mathrm{Al}_{2} \mathrm{TiO}_{5}-$ $0.5 \mathrm{MgTi}_{2} \mathrm{O}_{5}\left(\mathrm{AlTi}_{1.5} \mathrm{Mg}_{0.5} \mathrm{O}_{5}\right)$ solid solution, of which samples were prepared using the above-mentioned procedure.

Samples of $\mathrm{Fe}_{2} \mathrm{TiO}_{5}$ with an equimolar composition of $\mathrm{Fe}_{2} \mathrm{O}_{3}$ and $\mathrm{TiO}_{2}$ were crystallized into pseudobrookite-type titanate and hematite by heating at $1500^{\circ} \mathrm{C}$ in air. The crystallization of pseudobrookite-type titanate and hematite occurred because $\mathrm{Fe}^{3+}$ was partially reduced and formed a solid solution, $\mathrm{Fe}_{2} \mathrm{TiO}_{5-}$ $\mathrm{FeTi}_{2} \mathrm{O}_{5} .{ }^{16)}$ Then, the samples were sintered in an oxygen atmosphere $(50 \mathrm{~mL} / \mathrm{min})$ at 1200 and $1100^{\circ} \mathrm{C}$ and then annealed at lower temperatures of $1000^{\circ} \mathrm{C}$ for $8 \mathrm{~h}, 500$ and $400^{\circ} \mathrm{C}$ for $100 \mathrm{~h}$. These fired samples were furnace cooled in a flowing $\mathrm{O}_{2}$ atmosphere.

The fired samples were crushed and the cation distribution was estimated by the Rietveld method (PDXL2 program, Rigaku, Japan). The X-ray diffraction (XRD) intensity was collected for $6 \mathrm{~s}$ every $0.02^{\circ}$ intervals using a usual Bragg-Brentano type diffractometer (Ultima IV, Rigaku, Japan). In the estimation of the occupancy of the cations, the occupancy of $\mathrm{Ti}^{4+}$ ions in the $4 \mathrm{c}$ site was set as a variable $x$ and the occupancies of the other ions in the sites were calculated. In the case of $\mathrm{Al}_{2} \mathrm{TiO}_{5}$, as listed in Table $1, \mathrm{Ti}^{4+}$ ions at the $8 \mathrm{f}$ site, $\mathrm{Al}^{3+}$ ions at the $4 \mathrm{c}$ site, and $\mathrm{Al}^{3+}$ ions in $8 \mathrm{f}$ site became $(1-x) / 2,(1-x)$, and $(1+x) / 2$, respectively. If cations are randomly distributed in the $4 \mathrm{c}$ and $8 \mathrm{f}$ sites of $\mathrm{Al}_{2} \mathrm{TiO}_{5}$ and $\mathrm{Fe}_{2} \mathrm{TiO}_{5}, x$ becomes 0.333 and $x=0.667$ for $\mathrm{MgTi}_{2} \mathrm{O}_{5}$. For the estimation of the cation distributions in the $0.5 \mathrm{Al}_{2} \mathrm{TiO}_{5}-0.5 \mathrm{MgTi}_{2} \mathrm{O}_{5}$ solid solution, however, a different vari- able was used, which will be mentioned later. It is noteworthy that in $\mathrm{Al}_{2} \mathrm{TiO}_{5}$ and $\mathrm{Fe}_{2} \mathrm{TiO}_{5}$, a perfect cation site preference was only achieved with $x=1$, while $x=0$ gave a random distribution of the same number of $\mathrm{Al}^{3+}$ and $\mathrm{Ti}^{4+}$ ions in the $8 \mathrm{f}$ cation site and the $4 \mathrm{c}$ site was occupied by $\mathrm{Al}^{3+}$ ion. In the case of $\mathrm{MgTi}_{2} \mathrm{O}_{5}$, $x=0$ gives perfect site preference. By changing the value $x$, the minimum values of $R_{\mathrm{wp}}$ indicated the most reliable structure and cation distribution. Using the estimated atomic positions, interionic distances were also calculated.

The Rietveld analysis was performed for $\mathrm{Al}_{2} \mathrm{TiO}_{5}$ samples heated at $1500^{\circ} \mathrm{C}$ for $2 \mathrm{~h}$, and then annealed at 1300 and $500^{\circ} \mathrm{C}$ for $100 \mathrm{~h}$, and at 1200 and $1100^{\circ} \mathrm{C}$ for $1 \mathrm{~h} ; \mathrm{Fe}_{2} \mathrm{TiO}_{5}$ samples heated at 1200 and $1100^{\circ} \mathrm{C}$ for $2 \mathrm{~h}$, at $1000^{\circ} \mathrm{C}$ for $8 \mathrm{~h}$, at 500 and $400^{\circ} \mathrm{C}$ for $100 \mathrm{~h}$ in an $\mathrm{O}_{2}$ atmosphere; $\mathrm{MgTi}_{2} \mathrm{O}_{5}$ samples heated at $1500^{\circ} \mathrm{C}$ for $2 \mathrm{~h}$ and annealed at 1400 to $400^{\circ} \mathrm{C}$ for 100 and $200 \mathrm{~h}$; and $\mathrm{AlTi}_{1.5} \mathrm{Mg}_{0.5} \mathrm{O}_{5}$ solid solution samples heated at $1500^{\circ} \mathrm{C}$ for $2 \mathrm{~h}$ and annealed at $1200^{\circ}, 1100$ and $500^{\circ} \mathrm{C}$ for $100 \mathrm{~h}$.

\section{Results and discussion}

\subsection{Crystalline phases of the sintered and an- nealed samples}

$\mathrm{Al}_{2} \mathrm{TiO}_{5}, \mathrm{MgTi}_{2} \mathrm{O}_{5}$ and $\mathrm{AlTi}_{1.5} \mathrm{Mg}_{0.5} \mathrm{O}_{5}$ samples were crystallized into pseudobrookite-type compounds by sintering at $1500^{\circ} \mathrm{C}$. By annealing at 1100 and $1200^{\circ} \mathrm{C}$ for $1 \mathrm{~h}, \mathrm{Al}_{2} \mathrm{TiO}_{5}$ was partially decomposed into rutile and corundum, as shown in Fig. 1 (left). Their decomposition ratios were 14 and 4\%, respectively, and these samples were analyzed by the Rietveld method. After the longer annealing time of $10 \mathrm{~h}$ at $1200^{\circ} \mathrm{C}, \mathrm{Al}_{2} \mathrm{TiO}_{5}$ was completely decomposed, as also shown in Fig. 1 (left). Annealing at a lower temperature of $600^{\circ} \mathrm{C}$ for $100 \mathrm{~h}, \mathrm{Al}_{2} \mathrm{TiO}_{5}$ did not decompose. The solid solution of $\mathrm{AlTi}_{1.5} \mathrm{Mg}_{0.5} \mathrm{O}_{5}$ was more stable than pure $\mathrm{Al}_{2} \mathrm{TiO}_{5}$. This sample began to decompose after annealing at $1100^{\circ} \mathrm{C}$ for $100 \mathrm{~h}$ and was considerably, but not completely, decomposed at $1100^{\circ} \mathrm{C}$ for $200 \mathrm{~h}$ into rutile and spinel, as shown

Table 1. Variables of occupancy of cations in the two cation sites

\begin{tabular}{ccccc}
\hline $\mathrm{Al}_{2} \mathrm{TiO}_{5}$ and $\mathrm{Fe}_{2} \mathrm{TiO}_{5}$ & \multicolumn{2}{c}{$\mathrm{MgTi}_{2} \mathrm{O}_{5}$} \\
\hline \multirow{2}{*}{$4 \mathrm{c}$} & $\mathrm{Ti}^{4+}$ & $x$ & $\mathrm{Ti}^{4+}$ & $x$ \\
& $\mathrm{Al}^{3+}$ & $1-x$ & $\mathrm{Mg}^{2+}$ & $1-x$ \\
\hline \multirow{2}{*}{$8 \mathrm{f}$} & $\mathrm{Ti}^{4+}$ & $(1-x) / 2$ & $\mathrm{Ti}^{4+}$ & $(2-x) / 2$ \\
& $\mathrm{Al}^{3+}$ & $(1+x) / 2$ & $\mathrm{Mg}^{2+}$ & $x / 2$ \\
\hline
\end{tabular}

\begin{tabular}{ccc}
\hline \multicolumn{3}{c}{$\mathrm{AlTi}_{1.5} \mathrm{Mg}_{0.5} \mathrm{O}_{5}$} \\
\hline \multirow{3}{*}{$\mathrm{Mg}^{2+}$} & $y$ \\
$4 \mathrm{c}$ & $\mathrm{Ti}^{4+}$ & $3(1-y) / 5$ \\
& $\mathrm{Al}^{3+}$ & $2(1-y) / 5$ \\
\hline \multirow{3}{*}{$\mathrm{Mg}^{2+}$} & $(1-2 y) / 4$ \\
$8 \mathrm{f}$ & $\mathrm{Ti}^{4+}$ & $3(3+2 y) / 20$ \\
& $\mathrm{Al}^{3+}$ & $2(3+2 y) / 20$
\end{tabular}

$\mathrm{AlTi}_{1.5} \mathrm{Mg}_{0.5} \mathrm{O}_{5}$
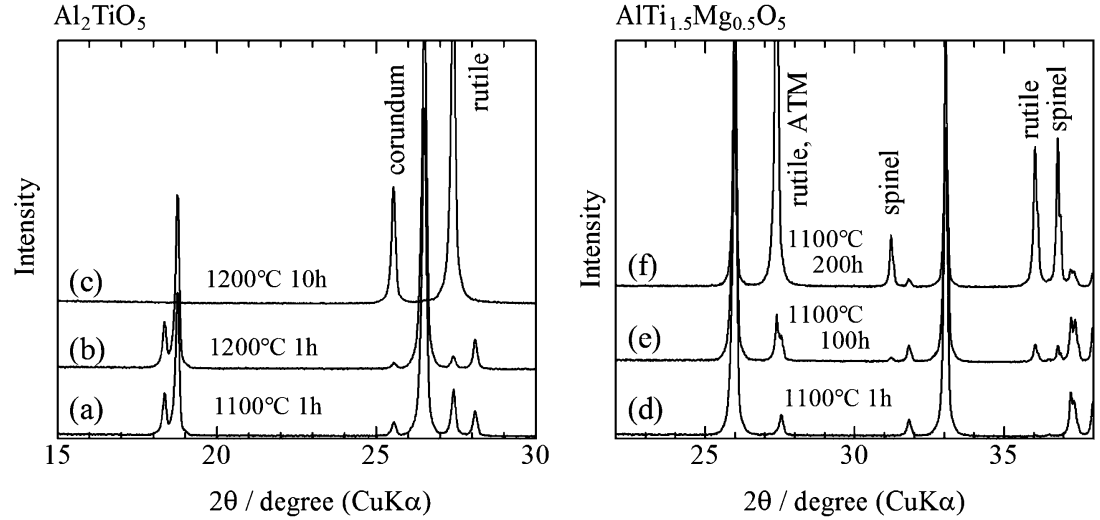

Fig. 1. XRD profiles of $\mathrm{Al}_{2} \mathrm{TiO}_{5}$ with composition of $\mathrm{Al}_{2} \mathrm{O}_{3}: \mathrm{TiO}_{2}=1.02: 1$ (left) and $\mathrm{AlTi}_{1.5} \mathrm{Mg}_{0.5} \mathrm{O}_{5}$ (right) samples fired at $1500^{\circ} \mathrm{C}$ for $2 \mathrm{~h}$, and then annealed (a) at $1100^{\circ} \mathrm{C}$ for $1 \mathrm{~h}$, (b) at $1200^{\circ} \mathrm{C}$ for $1 \mathrm{~h}$, and (c) at $1200^{\circ} \mathrm{C}$ for $10 \mathrm{~h}$ for $\mathrm{Al}_{2} \mathrm{TiO}_{5}$, and (d) $1100^{\circ} \mathrm{C}$ for $1 \mathrm{~h}$, (e) $1100^{\circ} \mathrm{C}$ for $100 \mathrm{~h}$, and (f) $1100^{\circ} \mathrm{C}$ for $200 \mathrm{~h}$ for $\mathrm{AlTi}_{1.5} \mathrm{Mg}_{0.5} \mathrm{O}_{5}$. Diffraction peaks of $\mathrm{Al}_{2} \mathrm{TiO}_{5}$ and $\mathrm{AlTi}_{1.5} \mathrm{Mg}_{0.5} \mathrm{O}_{5}$ (ATM) are not identified. 
in Fig. 1 (right). The $\mathrm{AlTi}_{1.5} \mathrm{Mg}_{0.5} \mathrm{O}_{5}$ sample did not decompose by annealing at $1200^{\circ} \mathrm{C}$ for $100 \mathrm{~h}$. These results are the same as those reported by Buscaglia et al. ${ }^{17}$ ) There was no change in the crystalline phases of $\mathrm{MgTi}_{2} \mathrm{O}_{5}$ and $\mathrm{Fe}_{2} \mathrm{TiO}_{5}$ by annealing.

\subsection{Electrostatic preference of the octahedra to cation distribution according to Pauling's sec- ond rule}

Typical result of Rietveld analysis for $\mathrm{Al}_{2} \mathrm{TiO}_{5}$ sample is shown in Fig. 2. The minimum $R_{\mathrm{wp}}$ occurred at $x=0.4$ and was independent of the annealing temperature. In the case of $\mathrm{Al}_{2} \mathrm{TiO}_{5}$, the structure with $x=0.4$ was most reliable regardless of the annealing temperature. The other titanates were examined in the same way, and Table 2 shows typical results from these examinations. Using the data from $\mathrm{Al}_{2} \mathrm{TiO}_{5}$ fired at $1500^{\circ} \mathrm{C}$, a schematic of four octahedra is shown in Fig. 3. In this figure, four oxide ions that are just above the cations are omitted. There are three types of oxide ions, one at the $4 \mathrm{c}$ site and two at $8 \mathrm{f}$ sites. The cations are situated inside each octahedron, but not at the center, because the octahedra are distorted. The three octahedra are connected by edge-sharing along the $b$-axis and the two octahedra of $8 \mathrm{f}$ cation are connected by apex-sharing with $\mathrm{O} 1$ ion. The apex connection causes the distortion of octahedra.

To examine the electrostatic stability, the number of cations around the anion was counted according to the calculated interionic distances listed in Table 3. Three types of oxide ions, one $4 \mathrm{c}$ and two $8 \mathrm{f}$, were surrounded by 3 or 4 cations, and beyond these surrounding cations, oxide ions appeared again. Thus the individual electrostatic bond strength between anions and cations was calculated as -2 divided by 3 or 4 . The sum of the six bond

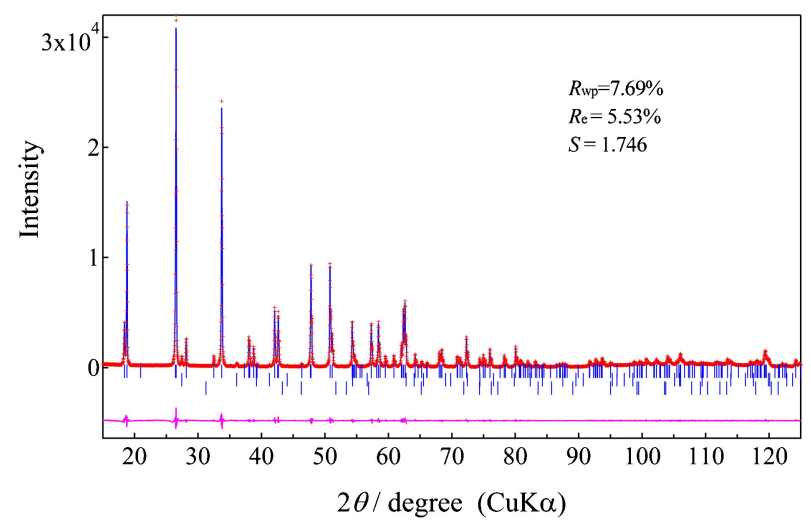

Fig. 2. XRD profile of $\mathrm{Al}_{2} \mathrm{TiO}_{5}$ with composition of $\mathrm{Al}_{2} \mathrm{O}_{3}: \mathrm{TiO}_{2}=$ $1: 1.02$ fired at $1500^{\circ} \mathrm{C}$ for $2 \mathrm{~h}$. strengths between anions and cations resulted in a value of -3.333 for both the $4 \mathrm{c}$ and $8 \mathrm{f}$ cation sites. The total charge of the cations was 10 , which was the same as that derived from the nominal formula of the pseudobrookite-type compounds. This means that the two cation sites are electrostatically equivalent and Pauling's second rule suggests no site preference for the cation.

\subsection{Cation distribution}

The obtained cation distributions against the annealing temperature are shown in Fig. 4. In Fig. 4(b), data reported by Wechsler and Navrotsky ${ }^{10)}$ are also plotted. The occupation of $\mathrm{Al}_{2} \mathrm{TiO}_{5}$ and $\mathrm{Fe}_{2} \mathrm{TiO}_{5}$ did not depend on the annealing temperature, while that of $\mathrm{MgTi}_{2} \mathrm{O}_{5}$ depended on the annealing temperature. The tendency and site occupation of the two cations of $\mathrm{MgTi}_{2} \mathrm{O}_{5}$ were almost the same as those reported by Wechsler and Navrotsky, and others. The large value of the sample annealed at 400 and $500^{\circ} \mathrm{C}$ is observed in Fig. 4(b). This was caused by very low diffusivity, they had not reached equilibrium.

As mentioned before, the random distribution of the cation results in $x=0.333$ in $\mathrm{Al}_{2} \mathrm{TiO}_{5}$ and $\mathrm{Fe}_{2} \mathrm{TiO}_{5}$ and $x=0.667$ in

Table 2. Typical results of Rietveld analysis, $\mathrm{Al}_{2} \mathrm{TiO}_{5}$ with composition of $\mathrm{Al}_{2} \mathrm{O}_{3}: \mathrm{TiO}_{2}=1: 1.02$ fired at $1500^{\circ} \mathrm{C}$ for $2 \mathrm{~h}$

\begin{tabular}{cccccccc}
\hline & $a_{0}$ & $b_{0}$ & $c_{0}$ & & $R_{\mathrm{wp}}$ & $R_{\mathrm{p}}$ & $S$ \\
\cline { 1 - 4 } $\begin{array}{c}\text { Lattice } \\
\text { constant } / \AA\end{array}$ & $9.4359(8)$ & $9.6425(7)$ & $3.5930(3)$ & & $7.69 \%$ & $5.53 \%$ & 1.746 \\
\cline { 1 - 3 } & & & & & & &
\end{tabular}

\begin{tabular}{ccccccc}
\hline Site & Ion & $x$ & \multicolumn{1}{c}{$y$} & $z$ & Occupation & $B / \AA^{2}$ \\
\hline \multirow{2}{*}{$\mathrm{M} 1,4 \mathrm{c}$} & $\mathrm{Ti}^{4+}$ & $0.18610(11)$ & 0.25 & 0 & 0.4 & $1.0461(11)$ \\
& $\mathrm{Al}^{3+}$ & & & & 0.6 & \\
\hline \multirow{2}{*}{$\mathrm{M} 2,8 \mathrm{f}$} & $\mathrm{Ti}^{4+}$ & \multirow{2}{*}{$0.13535(15)$} & $0.56157(12)$ & 0 & 0.3 & $0.69(3)$ \\
& $\mathrm{Al}^{3+}$ & & & & 0.7 & \\
\hline $\mathrm{O} 1,4 \mathrm{c}$ & $\mathrm{O}^{2-}$ & $0.7575(3)$ & 0.25 & 0 & 1 & $0.28(6)$ \\
$\mathrm{O} 2,8 \mathrm{f}$ & $\mathrm{O}^{2-}$ & $0.0478(2)$ & $0.11620(15)$ & 0 & 1 & $0.52(4)$ \\
$\mathrm{O} 3,8 \mathrm{f}$ & $\mathrm{O}^{2-}$ & $0.3126(2)$ & $0.07261(16)$ & 0 & 1 & $0.42(4)$ \\
\hline
\end{tabular}

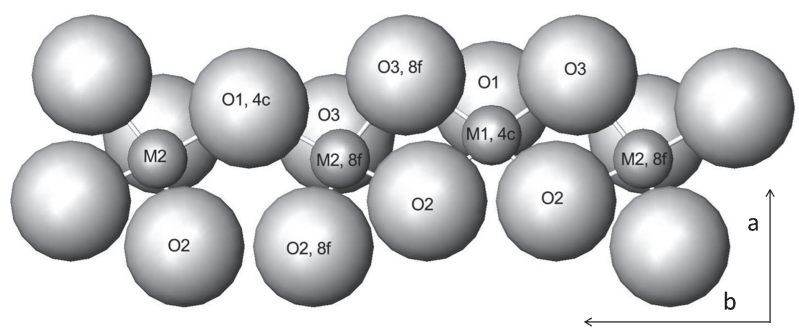

Fig. 3. Schematic of pseudobrookite-type $\mathrm{Al}_{2} \mathrm{TiO}_{5}$ structure.

Table 3. Neighboring ions and interionic distances $(\AA)$ around oxide ions, and electrostatic bond strength about the two octahedra of $\mathrm{Al}_{2} \mathrm{TiO}_{5}$ with composition of $\mathrm{Al}_{2} \mathrm{O}_{3}: \mathrm{TiO}_{2}=1: 1.02$ sample fired at $1500^{\circ} \mathrm{C}$ for $2 \mathrm{~h}$

\begin{tabular}{|c|c|c|c|c|c|c|c|}
\hline \multicolumn{2}{|c|}{ anion } & \multicolumn{2}{|c|}{$\mathrm{O} 1,4 \mathrm{c}$} & \multicolumn{2}{|c|}{$\mathrm{O} 2,8 \mathrm{f}$} & \multicolumn{2}{|c|}{$\mathrm{O} 3,8 \mathrm{f}$} \\
\hline \multicolumn{2}{|c|}{ nearest neighbor } & $\mathrm{M} 1 \times 2$ & 1.919 & $\mathrm{M} 2 \times 1$ & 1.807 & $\mathrm{M} 2 \times 2$ & 1.865 \\
\hline \multicolumn{2}{|c|}{ 2nd nearest } & $\mathrm{M} 2 \times 2$ & 2.079 & $\mathrm{M} 1 \times 1$ & 1.835 & $\mathrm{M} 1 \times 1$ & 2.086 \\
\hline \multicolumn{2}{|c|}{ 3rd nearest } & $\mathrm{O} 3 \times 4$ & 2.534 & $\mathrm{M} 2 \times 1$ & 1.903 & $\mathrm{M} 2 \times 1$ & 2.115 \\
\hline \multicolumn{2}{|c|}{ 4th nearest } & $\mathrm{O} 2 \times 4$ & 2.968 & $\mathrm{O} 2 \times 1$ & 2.416 & $\mathrm{O} 1 \times 2$ & 2.534 \\
\hline \multirow{2}{*}{ anion } & \multirow{2}{*}{$\begin{array}{l}\text { number of cation } \\
\text { surrounding anion }\end{array}$} & \multirow{2}{*}{\multicolumn{2}{|c|}{$\begin{array}{l}\text { electrostatic bond } \\
\text { strength of anion }\end{array}$}} & \multicolumn{2}{|c|}{$4 \mathrm{c}$ cation site } & \multicolumn{2}{|c|}{$8 \mathrm{f}$ cation site } \\
\hline & & & & number of anion & charge & number of anion & charge \\
\hline $\mathrm{O} 1,4 \mathrm{c}$ & 4 & & & 2 & -1 & 1 & -0.5 \\
\hline $\mathrm{O} 2,8 \mathrm{f}$ & 3 & & & 2 & -1.333 & 2 & -1.333 \\
\hline $\mathrm{O} 3,8 \mathrm{f}$ & 4 & & & 2 & -1 & 3 & -1.5 \\
\hline \multicolumn{4}{|c|}{ sum } & 6 & -3.333 & 6 & -3.333 \\
\hline
\end{tabular}



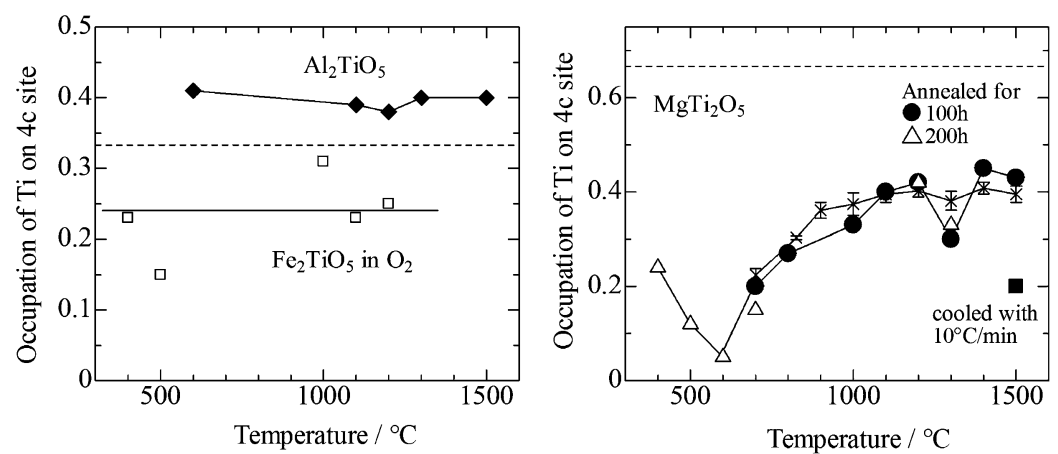

Fig. 4. Occupations of $\mathrm{Ti}^{4+}$ ion in $4 \mathrm{c}$ site, broken lines mean random occupation. Data of Wechsler and Navrotsky ${ }^{10)}$ are plotted by X with error bar.

Table 4. Bond valence sum (BVS) and calculated cation charges using nominal charge and weighted by the occupancy (weighted nominal charge, $\mathrm{WNC}$ )

\begin{tabular}{|c|c|c|c|c|c|c|c|c|c|}
\hline \multirow[b]{2}{*}{ site } & \multicolumn{3}{|c|}{$\begin{array}{c}\mathrm{Al}_{2} \mathrm{TiO}_{5}, 1500^{\circ} \mathrm{C} 2 \mathrm{~h} \\
x=0.4\end{array}$} & \multicolumn{3}{|c|}{$\begin{array}{c}\mathrm{Fe}_{2} \mathrm{TiO}_{5}, 1100^{\circ} \mathrm{C} 2 \mathrm{~h} \text { in } \mathrm{O}_{2} \\
x=0.23\end{array}$} & \multicolumn{3}{|c|}{$\begin{array}{c}\mathrm{MgTi}_{2} \mathrm{O}_{5}, 1500^{\circ} \mathrm{C} 2 \mathrm{~h} \\
x=0.43\end{array}$} \\
\hline & $4 c$ & $8 f$ & total & $4 \mathrm{c}$ & $8 \mathrm{f}$ & total & $4 \mathrm{c}$ & $8 f$ & total \\
\hline BVS & 3.18 & 3.11 & 9.40 & 3.19 & 3.30 & 9.80 & 2.99 & 3.44 & 9.87 \\
\hline WNC & 3.40 & 3.30 & 10 & 3.23 & 3.39 & 10 & 2.86 & 3.57 & 10 \\
\hline$(\mathrm{BVS}-\mathrm{WNC}) / \mathrm{WNC}$ & $-6.5 \%$ & $-5.8 \%$ & $-6.0 \%$ & $-1.2 \%$ & $-2.7 \%$ & $-2.0 \%$ & $4.5 \%$ & $-3.6 \%$ & $-1.3 \%$ \\
\hline
\end{tabular}

$\mathrm{MgTi}_{2} \mathrm{O}_{5}$. The cation distribution in $\mathrm{Al}_{2} \mathrm{TiO}_{5}$ was slightly larger than the value and $\mathrm{Ti}^{4+}$ ion slightly favors the $4 \mathrm{c}$ site, a tendency that was previously reported. ${ }^{13)}$ This value remains almost constant when varying the temperature, and therefore, the configuration entropy remained constant over the decomposition temperature range. It is notable that in the samples annealed at 1100 and $1200^{\circ} \mathrm{C}$, decomposition began and three phases, rutile, corundum and $\mathrm{Al}_{2} \mathrm{TiO}_{5}$, coexisted. This means that the decomposition of aluminum titanate was not induced by a decrease in the entropy, i.e., by increasing the site preference of cations. On the other hand, site preference in $\mathrm{MgTi}_{2} \mathrm{O}_{5}$ increased as the configuration entropy of this compound decreased at lower temperature. The decrease in the value of $x$ means that $\mathrm{Mg}^{2+}$ ion favored the $4 \mathrm{c}$ site at lower temperature.

In the case of the $\mathrm{AlTi}_{1.5} \mathrm{Mg}_{0.5} \mathrm{O}_{5}$ solid solution, there are three types of cations and a simplification is needed for the present Rietveld analysis. Because the $\mathrm{Ti}^{4+}$ and $\mathrm{Al}^{3+}$ ions in $\mathrm{Al}_{2} \mathrm{TiO}_{5}$ have little site preference, we assumed that these two ions have the same tendency of site occupancy, and the occupation of $\mathrm{Mg}^{2+}$ ion in $4 \mathrm{c}$ site is assigned as $y$. In this case, individual variations of the ions at the sites are listed in Table 1. In this solid solution, the random distribution gives $y=0.167$.

The resultant $y$ values giving the lowest $R_{\mathrm{wp}}$ were $0.23,0.20$, 0.29 , and 0.27 for samples heated at 1500, 1200, 1100 and $500^{\circ} \mathrm{C}$, respectively. Since the measured $y$ values were larger than the random distribution, the $\mathrm{Mg}^{2+}$ ion favored the $4 \mathrm{c}$ site, and this is the same tendency as $\mathrm{MgTi}_{2} \mathrm{O}_{5}$. The same dependence of the site preference on the temperature was also observed in this experiment, so that the $\mathrm{Mg}^{2+}$ ion preferred the $4 \mathrm{c}$ site at lower temperature.

\subsection{Bond valence sum of the octahedra}

For an estimation of the valence of the cation in the octahedron, a calculation of bond valence sum is often performed. ${ }^{18), 19)}$ Here, the bond valence sum was determined using the calculated distances from the central cation to the surrounding six oxide ions and was then compared with the result of the Rietveld analysis. The bond valence sum is derived by the equation below.

$$
V_{\mathrm{i}}=\sum_{\mathrm{j}} \exp \left(\frac{l_{0}-l_{\mathrm{ij}}}{B}\right)
$$

where $V_{\mathrm{i}}$ : effective valence of i cation; $l_{0}$ : constant for specific pair of oxide ion and cation, ${ }^{18)}$ which was calculated by weighing the occupancy of the cations in the sites; $B$ : constant $0.37 ; l_{\mathrm{ij}}$ : measured distance between the $i$ cation and $j$ anion. The calculated bond valence sums and the estimated charge of the cation, which is calculated from the nominal charge weighted by the cation occupations, are listed in Table 4.

The charge of the cations by the bond valence sum and weighted nominal charge agreed to within approximately $5 \%$. The estimated distributions of the cations in the octahedra by the Rietveld method are quite reasonable. The bond valence sums of $\mathrm{Al}_{2} \mathrm{TiO}_{5}$ were smaller than those of the weighted nominal values by 6.5 and $5.8 \%$ for the $4 \mathrm{c}$ and $8 \mathrm{f}$ sites, respectively. This means that the octahedra of $\mathrm{Al}_{2} \mathrm{TiO}_{5}$ are "stretched" according to a description in the Section 8.3 of Ref. 19, i.e., the bond lengths, as a whole of octahedron, between the cation and surrounding oxide ions are longer than that expected from usual relation of the cation and oxide ions. The cations in the octahedra are smaller than the space formed in the six coordinated oxide ions. The large bond valence sum of the $4 \mathrm{c}$ site in $\mathrm{MgTi}_{2} \mathrm{O}_{5}$ would mean that the octahedron is "compressed", i.e., the bond lengths are shorter than that expected from cation and oxide ions. In this case the ion size of $\mathrm{Mg}^{2+}$ is too large for the $4 \mathrm{c}$ site, although $\mathrm{Mg}^{2+}$ ion tends to enter this site. The deviation of the calculated bond valence sum from the nominal valence of the ion is a simple measure to suggest how the cation fit in the octahedron of oxide ions. The relation between the size of cation and cavity of the octahedron is also shown in the next section.

\subsection{Size and shape of the octahedra and site preference}

As seen previously, the two cation sites are electrostatically equivalent, so the cation size and octahedron size should affect the site preference of cations. Using the obtained parameters, the volume of the two octahedra was calculated and is shown in 
Fig. 5. The $4 \mathrm{c}$ cation octahedron is smaller than the $8 \mathrm{f}$ cation octahedron, although the large $\mathrm{Mg}^{2+}$ ion tended to enter the $4 \mathrm{c}$ site at a lower temperature. As shown in Fig. 3, the two octahedra are distorted and the volume itself is not a measure of the capability of accommodating the large cation. To show the distortion of the octahedra, the distances between the central cation and surrounding six oxide ions were calculated and are shown in Fig. 6. In this figure, the sum of the ionic radii of the cations and oxide ion is also shown. The ionic radii of the cations were those of coordination number 6 , after Schannon. ${ }^{20)}$ For the ionic radius of the oxide ion, the radius for the coordination number $4,1.38$, and $3,1.36 \AA$, was averaged with the weight of the number of oxide ions in the pseudobrookite-type structure, 3 and 2, respectively. The variations of the distance were large in the $8 \mathrm{f}$ cation site, which is marked by a triangle, while those of the $4 \mathrm{c}$ cation site, square mark, depended on the compounds.

$\mathrm{Al}^{3+}$ has a small ionic radius, and its cation-anion distances exhibited the smallest values. The distance between $\mathrm{Ti}^{4+}$ or $\mathrm{Fe}^{3+}$ and the oxide ions is very similar to the average cation-anion distance of the octahedra. The "stretched" nature of $\mathrm{Al}_{2} \mathrm{TiO}_{5}$ derived from the bond valence sum is attributed to the small size of $\mathrm{Al}^{3+}$.

Both octahedra were distorted, and the variation of the cationanion distances of the $8 \mathrm{f}$ cation octahedron was large and almost

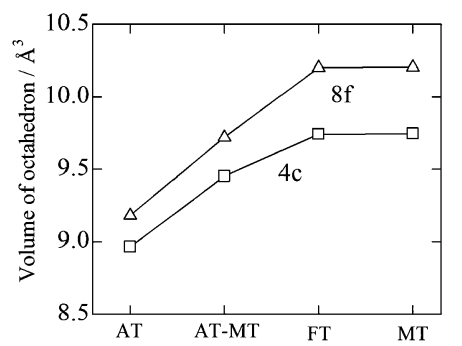

Fig. 5. Volumes of the two octahedra, $4 \mathrm{c}$ and $8 \mathrm{f}$.

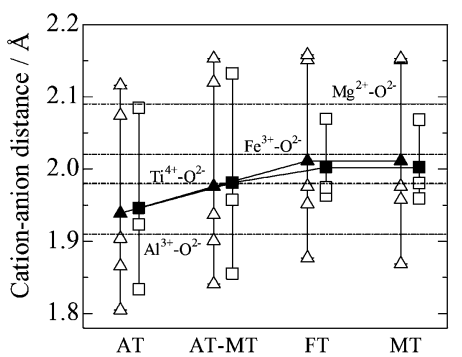

Fig. 6. Distances between central cations and coordinated anions, square marks: $4 \mathrm{c}$ cation site, triangle marks: $8 \mathrm{f}$ cation site, solid marks: averaged distance, and open marks: individual distance. Summations of ionic radii of oxide ion and cations are also shown. the same among the titanates examined. On the other hand, the variation of the cation-anion distances of the $4 \mathrm{c}$ cation octahedron became small by increasing the cation size, i.e., going from $\mathrm{Al}^{3+}$ to $\mathrm{Fe}^{3+}$ and $\mathrm{Mg}^{2+}$. This means that the octahedron of the larger cation becomes a nearly "regular" octahedron and the effective space to accommodate the cation becomes larger.

The distorted octahedra also result in a deviation of the cation position from the center of the six surrounding oxide ions. The difference in the position between the actual cation and the average of the positions of the six oxide ions was calculated as a distance between two centers and is shown in Fig. 7. The distance between the centers in the $8 \mathrm{f}$ cation site was almost the same among the titanates. The distance in the $4 \mathrm{c}$ site is smaller for titanates with larger cations and the $4 \mathrm{c}$ cation located near the center of the octahedron.

In other words, large cations can make the distorted $4 \mathrm{c}$ octahedron regular, and large cations tend to enter this $4 \mathrm{c}$ site. As shown in Fig. 3, an $\mathrm{O} 1$ ion in the $8 \mathrm{f}$ cation octahedron bridges the two octahedra, and this distortion renders the octahedron unsuitable for accommodating large cations. In the case of $\mathrm{Fe}_{2} \mathrm{TiO}_{5}$, the ionic radii of $\mathrm{Fe}^{3+}$ and $\mathrm{Ti}^{4+}$ are similar and no significant site preference occurs. This is a possible explanation for why $\mathrm{Mg}^{2+}$ ions prefer the small $4 \mathrm{c}$ site at lower temperature.

\subsection{Configuration entropy and contribution to the stability of the titanates}

Configuration entropy stabilizes pseudbrookite-type titanates, especially at high temperature. Using the above-estimated cation distribution, the configuration entropy, $S_{\text {conf }}$, was calculated as ${ }^{21)}$

$$
S_{\text {conf }}=-R \sum b_{\mathrm{s}} N_{\mathrm{s}}^{\mathrm{i}} \cdot \ln N_{\mathrm{s}}^{\mathrm{i}}
$$

where $R$ is the ideal gas constant, $b_{\mathrm{s}}$ is the number of s sites per formula unit, and $N_{\mathrm{s}}^{\mathrm{i}}$ is the fraction of i species in s site. The results are shown in Fig. 8. The $S_{\text {conf }}$ of $\mathrm{Al}_{2} \mathrm{TiO}_{5}$ is approximately $15 \mathrm{Jmol}^{-1} \mathrm{~K}^{-1}$. The contribution of configuration entropy to the free energy, $T \Delta S_{\text {conf }}$, is also plotted against temperature in

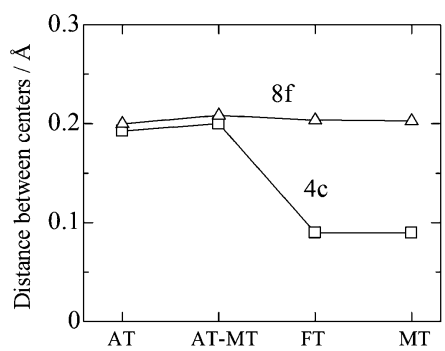

Fig. 7. Distances between two centers, i.e., between cation position and average of six surrounding oxide ions.

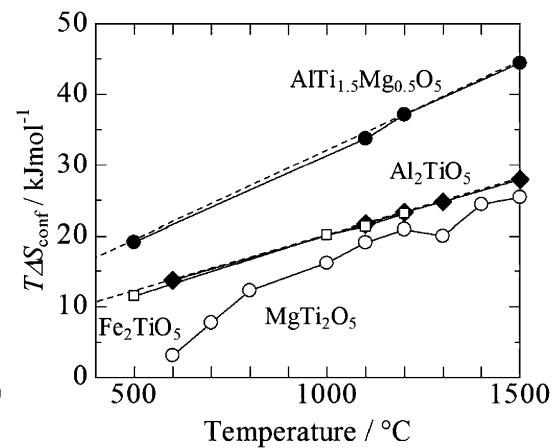

Fig. 8. Configuration entropy $S_{\text {conf }}$ and $T \Delta S_{\text {conf }} \mathrm{Al}_{2} \mathrm{TiO}_{5}$ was partially decomposed at 1100 and $1200^{\circ} \mathrm{C}$. 
Table 5. Formation free energy of some oxides

\begin{tabular}{cc}
\hline oxide & $\Delta G^{0}$ at $1000 \mathrm{~K}, \mathrm{~kJ} / \mathrm{mol}$ \\
\hline $\mathrm{Fe}_{2} \mathrm{O}_{3}$, hematite & -987.4 \\
$\mathrm{Al}_{2} \mathrm{O}_{3}$, corundum & -1778.6 \\
$\mathrm{TiO}_{2}$, rutile & -1027.9 \\
$\mathrm{MgO}$, periclase & -651.1 \\
$\mathrm{Al}_{2} \mathrm{O}_{3}+\mathrm{TiO}_{2}$ & -2806.6 \\
$\mathrm{Fe}_{2} \mathrm{O}_{3}+\mathrm{TiO}_{2}$ & -2015.3 \\
$\mathrm{MgO}+2 \mathrm{TiO}_{2}$ & -2707.0 \\
\hline
\end{tabular}

Fig. 8. The graph contains data from the $\mathrm{AlTi}_{1.5} \mathrm{Mg}_{0.5} \mathrm{O}_{5}$ solid solution.

Gani and McPherson ${ }^{22)}$ reported the formation enthalpy $\Delta H_{\mathrm{f}}$ of $\mathrm{Al}_{2} \mathrm{TiO}_{5}$ from rutile and corundum as $25.1 \mathrm{kJmol}^{-1}$ at $1340^{\circ} \mathrm{C}$. Considering this reaction occurred at an equilibrium temperature, the relation $\Delta H_{\mathrm{f}}=\Delta S_{\mathrm{f}} / T_{\mathrm{f}}$ gives $\Delta S_{\mathrm{f}}=15.6 \mathrm{Jmol}^{-1} \mathrm{~K}^{-1}$, and this value is almost the same as the configuration entropy shown in Fig. 8.

The configuration entropy of $\mathrm{Al}_{2} \mathrm{TiO}_{5}$ and $\mathrm{Fe}_{2} \mathrm{TiO}_{5}$ is almost the same as that of a random configuration, although there is some degree of site preference, as shown in Fig. 4. This also suggests that there is little motive force toward the perfect random distribution energetically. The difference between the configuration entropy values of $\mathrm{Al}_{2} \mathrm{TiO}_{5}$ and $\mathrm{MgTi}_{2} \mathrm{O}_{5}$, and $\mathrm{AlTi}_{1.5} \mathrm{Mg}_{0.5} \mathrm{O}_{5}$ solid solution means stabilizing effect by the solid solution. Buscaglia et al. ${ }^{17)}$ estimated the stabilizing effect of $\mathrm{Al}_{2} \mathrm{TiO}_{5}$ by doping $\mathrm{MgTi}_{2} \mathrm{O}_{5}$ under the assumption that the cation distribution was random. As shown in Fig. 8, their assumption is almost correct.

The stabilization effect of the configuration entropy on $\mathrm{Al}_{2} \mathrm{TiO}_{5}$ is large. It is true that $\mathrm{Al}_{2} \mathrm{TiO}_{5}$ is stabilized by an increase of configuration entropy, so the formation reaction from corundum and rutile is endothermic. However, it is not true that a decrease in the configuration entropy triggers the decomposition reaction of $\mathrm{Al}_{2} \mathrm{TiO}_{5}$ because partially decomposed $\mathrm{Al}_{2} \mathrm{TiO}_{5}$ exhibits an almost random cation distribution, as shown in Fig. 8. The decomposition of $\mathrm{Al}_{2} \mathrm{TiO}_{5}$ occurs at lower temperature, due to the lower thermodynamic free energy of an equimolar mixture of corundum and rutile than that of $\mathrm{Al}_{2} \mathrm{TiO}_{5}$. If the thermodynamic free energy is compared with, for example, a gel state of mixture of $\mathrm{Ti}^{4+}$ and $\mathrm{Al}^{3+}, \mathrm{Al}_{2} \mathrm{TiO}_{5}$ would be more stable than the gel. In a certain sol-gel route, $\mathrm{Al}_{2} \mathrm{TiO}_{5}$ readily crystallizes at lower temperature of 600 or $700^{\circ} \mathrm{C}$ as a metastable phase. ${ }^{23), 24)}$ It evidently show that $\mathrm{Al}_{2} \mathrm{TiO}_{5}$ is more stable than the gel. Because the $\mathrm{TiO}_{2}$ component is the same among the titanates of the present study, a stability of corundum would be attributed to the low temperature decomposition of $\mathrm{Al}_{2} \mathrm{TiO}_{5}$.

Table 5 shows the free energy of formation at $1000 \mathrm{~K}$ of some oxides concerning the three pseudobrookite oxides, which are calculated using thermodynamic constants from the textbook of Kubaschewski. ${ }^{25)}$ Obviously, corundum is a very stable oxide and compounds containing the $\mathrm{Al}_{2} \mathrm{O}_{3}$ species must overcome the stability of corundum to exist stably. Additionally, the "stretched" structure of $\mathrm{Al}_{2} \mathrm{TiO}_{5}$, which is mentioned in the consideration of the bond valence sum, would mean that this ionic compound has a low electrostatic lattice enthalpy because the lattice enthalpy is inversely proportional to the interionic distances and a "stretched" structure means longer interionic distances.

\section{Conclusion}

The cation distribution and interionic distances of three pseudobrookite type oxides, $\mathrm{Al}_{2} \mathrm{TiO}_{5}, \mathrm{MgTi}_{2} \mathrm{O}_{5}$ and $\mathrm{Fe}_{2} \mathrm{TiO}_{5}$, and a solid solution of $\mathrm{Al}_{2} \mathrm{TiO}_{5}-\mathrm{MgTi}_{2} \mathrm{O}_{5}$ were examined using $\mathrm{X}$-ray diffraction and the Rietveld method. The cation distributions in two types of octahedra of $\mathrm{Al}_{2} \mathrm{TiO}_{5}$ and $\mathrm{Fe}_{2} \mathrm{TiO}_{5}$ showed little preference and were independent of temperature. The configuration entropies of these oxides, however, were almost the same as that of a random distribution of cations. A cation distribution preference was observed in $\mathrm{MgTi}_{2} \mathrm{O}_{5}$ and found to exhibit temperature dependence; as the temperature was lowered, large $\mathrm{Mg}^{2+}$ ions tended to enter smaller $4 \mathrm{c}$ sites of the octahedron. The calculated bond valence sums of the titanates correspond to the cation distribution of the Rietveld analysis. Decomposition of $\mathrm{Al}_{2} \mathrm{TiO}_{5}$ is not triggered by a change in the cation distribution, but thermodynamic stability of corundum may cause the decomposition of $\mathrm{Al}_{2} \mathrm{TiO}_{5}$.

\section{References}

1) G. Bayer, J. Less-Common Met., 24, 129-138 (1971)

2) W. R. Buessem, N. R. Thielke and R. V. Sarakauskas, Ceram. Age, 60, 38-40 (1952).

3) J. J. Cleveland and R. C. Bradt, J. Am. Ceram. Soc., 61, 478481 (1978).

4) Y. Ohya, Z. Nakagawa and K. Hamano, J. Am. Ceram. Soc., 70, C184-C186 (1987).

5) S. B. Ogunwumi, P. D. Tepesch, T. Chapman, C. J. Warren, I. M. Melscoet-Chauvel and D. L. Tennent, Aluminum titanate compositions for diesel particulate filters, SAE Technical Paper Series, 2005-01-0583.

6) R. Papitha, M. B. Suresh and R. Johnson, Int. J. Appl. Ceram. Tec., 11, 773-782 (2014).

7) K. Hamano, Y. Ohya and Z. Nakagawa, Int. J. High Technol. Ceram., 1, 129-137 (1985).

8) Y. Ohya, S. Yamamoto, T. Ban, M. Tanaka and S. Kitaoka, J. Eur. Ceram. Soc., 37, 1673-1680 (2017).

9) E. Kato, K. Daimon and J. Takahashi, J. Am. Ceram. Soc., 63, 355-356 (1980).

10) B. A. Wechsler and A. Navrotsky, J. Solid State Chem., 55, 165-180 (1984).

11) N. E. Brown and A. Navrotsky, Am. Mineral., 74, 902-912 (1989).

12) H. Yang and R. M. Hazen, J. Solid State Chem., 138, 238-244 (1998).

13) S. Norberg, N. Ishizawa, S. Hoffmann and M. Yoshimura, Acta Crystallogr. E, 61, i160-i162 (2005).

14) R. D. Skala, D. Li and I. M. Low, J. Eur. Ceram. Soc., 29, 6775 (2009).

15) L. Pauling, Z. Krist., 73, 97-112 (1930).

16) W. Q. Guo, S. Malus, D. H. Ryan and Z. Altounisn, J. Phys.Condens. Mat., 11, 6337-6346 (1999).

17) V. Buscaglia, G. Battilana, M. Leoni and P. Nanni, J. Mater. Sci., 31, 5009-5016 (1996).

18) I. D. Brown and D. Altermatt, Acta Crystallogr. B, 41, 244247 (1985).

19) I. D. Brown, Chem. Rev., 109, 6858-6919 (2009).

20) R. D. Schannon, Acta Crystall. A-Crys., 32, 751-767 (1976).

21) A. Navrotsky and O. J. Kleppa, J. Inorg. Nucl. Chem., 30, 2701-2714 (1976).

22) M. S. J. Gani and R. McPherson, Thermochim. Acta, 7, 251252 (1973).

23) L. Bonhomme-Coury, N. Lequeux, S. Mussotte and P. Boch, J. Sol-Gel Sci. Techn., 2, 371-375 (1994).

24) M. Andrianainarivelo, R. J. P. Corriu, D. Leclercq, P. H. Mutin and A. Vioux, J. Sol-Gel Sci. Techn., 8, 89-93 (1997).

25) O. Kubaschewski, C. B. Alcock and P. J. Spencer, "Materials Thermochemistry", 6th ed. Oxford: Pergamon Press (1993). 